\title{
Effect of Nigella sativa and Carthamus tinctorius L. Oils on Various Biochemical Parameters of Streptozotocin-induced Diabetic Rats
}

\section{Moftah, Rofida F.; M.R.A. Rashwan; A.S. Abdel-Gawad and Magda A.A. Seleim}

Food Science and Technology Department, Faculty of Agriculture, Assiut University, Assiut, Egypt

Received on: 19/6/2018

Accepted for publication on: $26 / 6 / 2018$

\section{Abstract}

Effect of Nigella sativa and Carthamus tinctorius L. oils on some biochemical parameters was investigated in streptozotocin (STZ)-induced diabetic male Wistar rats. STZ-induced diabetic rats showed significant increases in the levels of blood glucose, triglycerides, cholesterol, low density lipoprotein LDLcholesterol, creatinine, urea, alanine aminotransferase (ALT) and aspartate aminotransferase (AST), while body weight, high density lipoprotein HDLcholesterol, total protein levels were significantly decreased compared to normal rats. Administration of the tested oils to diabetic rats resulted in a significant decrease in blood glucose, triglycerides, cholesterol, LDL-cholesterol, urea, AST and ALT while body weight and HDL-cholesterol level was markedly increased after three weeks compared to untreated diabetic rats. The results of this study indicate that the tested oils possess hypoglycemic, hypolipidemic and antioxidant effects in STZ-induced diabetic rats.

Keywords: Nigella sativa; Carthamus tinctorius L; Oil; Streptozotocin; Diabetes; Rats.

\section{Introduction}

Diabetes mellitus (DM) is one of the most common metabolic disorder worldwide, characterized by increase the blood glucose concentration due to deficiency of insulin secretion (Yoon et al., 2006). This leads to oxidative stress, it appears mainly due to enhance the production of free radicals and decrease antioxidant substances (Hayoz et al., 1998). The plants which contain antioxidants has been suggested as an integral treatment for blood glucose control (Bonnefont-Rousselot et al., 2000) as well as, the assessment of this natural origin of novel compounds is a right method for improvement of new antidiabetic treatment (Rchid et al., 2004).

Nigella sativa (N. sativa) is a genus belonging to family Ranuncu- laceae. A natural plant which is prevalently called with various names of dark cumin, dark seed and the seed of gift (Habatul-barakah). The seeds have been applied for several of years as a food additive and as a medical treatments (Halawani, 2009). Nigella sativa has been used as carminative, anthelmintics, diuretic as well as, treatment of cold, fever, antirheumatic and against poison of snakes and scorpions (Goreja, 2003; Arici et al., 2005; Padhye et al., 2008; AbdelSater, 2009). Nowadays, black seeds act as antibacterial, stimulate the immune system (Abel-Salam, 2012), decrease the blood pressure (Ali and Blunden, 2003), anti-inflammatory (El Mezayen et al., 2006; Shuid et al., 2012), anticancer (Mahmoud and Torchilin, 2013), antioxidant (Bourgou et al., 2012; Umar et al., 
2012) and antidiabetic (Abdelmeguid et al., 2010; Salama, 2012).

Carthamus tinctorius L. (safflower) (Compositae Family) is cultivated in Iran, the northwest India and some areas of Africa (Liu et al., 2005). The therapeutic parts are blooms, seeds and the extracted oil from its developing seed embryos. The bloom extracts have been mentioned as antibacterial agent, enhance of peripheral blood circulation, prevention of blood platelet aggregation, decrease growth of skin tumor in mice and anti-inflammatory properties (Hiramatsu et al., 2009). In addition, the antioxidant activity was reported (Choi et al., 2010).

The study aimed to investigate if the administration of $N$. sativa, Carthamus tinctorius L. and N. sativa plus Carthamus tinctorius L. oils have useful effects on some biochemical parameters in STZ-induced diabetic rats.

\section{Materials and methods}

Oils: Nigella sativa and Carthamus tinctorius oils were purchased from the factory in Qus, Qena Governorate, Egypt. The factory used the dry method for extraction of the oil from seeds.

Chemicals: Streptozotocin (STZ) was purchased from Sigma Chemical Company (Germany). Freshly prepared STZ at a dose of 60 $\mathrm{mg} / \mathrm{kg}$ dissolved in $0.01 \mathrm{M}$ citrate buffer, $\mathrm{pH}$ 4.5. 25\%, Glucose and $0.9 \% \mathrm{NaCl}$.

Animals: 60 Wister-albino male rats, weighing 200-250 g with approximately 60 days old were used. The animals were put in stainless steel cages $\left(30 \times 50 \times 25 \mathrm{~cm}^{3}\right.$ dimension). Diabetes was induced by a sin- gle intraperitonial injection of streptozotocin at a dose of $60 \mathrm{mg} / \mathrm{kg}$ body weight. While control rats received only the saline solution $(0.9 \% \mathrm{NaCl})$ in the same volume and through the same route.. After 2 days, the fasting blood glucose levels were determined from tail blood samples by using an OneTouch Ultra ${ }^{\circledR}$ glucometer. Rats with blood glucose levels more than $277 \mathrm{mg} / \mathrm{dL}$ were considered diabetic and used for the experiment.

\section{Experimental design and blood samples:}

Rats were randomly divided into five groups as the following: Group1: Normal control (nondiabetic rats) received normal diet, Group2: STZ-Control (diabetic control rats) received the same diet given in Group 1, Group 3: diabetic rats received the same diet given in Group 1 plus $4 \mathrm{ml} / \mathrm{kg}$ body weight $N$. sativa oil, Group 4: diabetic rats received the same diet given in Group 1 plus $4 \mathrm{ml} / \mathrm{kg}$ body weight safflower oil, Group 5: diabetic rats received the same diet given in Group 1 plus a blend of $4 \mathrm{ml} / \mathrm{kg}$ body weight $N$. sativa oil and safflower oil (50/50). All groups received the treatment by intragastric catheter, one time per day for 21 days. Blood glucose level and body weight have been measured each week. At the end of the experiment, blood samples were collected from the orbital venous plexus of the rat and were centrifuged in a Nahita centrifuge model 2698 (GALILEO, Madrid, Spain) at 3000 rpm for 10 minutes to obtain a clear serum. The serum was stored at $20^{\circ} \mathrm{C}$ for analyses of different biochemical parameters using commercial kits. 
Biochemical assay: The measured parameters were total protein, aspartate aminotransferase (AST), alanine aminotransferase (ALT), creatinine, urea, triglycerides, cholesterol, high-density lipoprotein cholesterol (HDL-C) and low density lipoprotein cholesterol (LDL-C), by using DR-7000D Semi-Automatic Chemistry Analyzer (DIRUI, Changchun, China).

\section{Result and Discussion}

\section{Effect of $N$. sativa and safflower oil on body weight}

There were a progressive increase in the body weight of control group while, STZ induced diabetic rats have decreased in the body weight. As well as, the groups which were treated by $N$. sativa oil, safflower oil or $N$. sativa plus safflower oils had higher body weight changes (Table 1). Thus, several studies demonstrated that the diabetic rats had significantly lower weight gain than the controls (Ananthi et al., 2003; Howarth et al., 2005; AlRawi, 2007). A decline in body weight of diabetic rats is conceivable because of catabolism of fats and protein, despite the fact that the food consumption is more in diabetic rats than control. Besides, insulin deficiency lead to diminish the protein content in the muscle by proteolysis (Vats et al., 2004). However, the increase the body gain in treated rats may be clarified by increased insulin production or increased food intake (Fernstrom and Fernstrom, 1993; Farouque and Meredith, 2003).
Effect of $N$. sativa and safflower oil on blood glucose level

The mean values of blood glucose of both control and experimental groups are showed in Table 2. STZ-incited diabetic rats presented a highly significant $(\mathrm{p}<0.001)$ increase in blood glucose levels, about $497.3 \mathrm{mg} / \mathrm{dl}$ following three weeks contrasted with the controls. Intraoral injection of $N$. sativa oil, safflower oil and $N$. sativa plus safflower oils to diabetic rats resulted in a highly significant $(\mathrm{p}<0.001)$ decrease in blood glucose levels of 133.9, 153.7 and 142.4 $\mathrm{mg} / \mathrm{dl}$ respectively, after three weeks, compared to untreated diabetic rats. On the other hand, diabetic rats treated by $N$. sativa oil had the lowest blood glucose level. A significant increase in blood glucose level of diabetic rat is consistent with the finding of Augusti and Sheela (1996) and Campos et al. (2003) in rats, (Kumar and Reddy, 1999). Various studies showed that an assortment of plant extracts successfully down the blood glucose level (Ravi et al., 2004; Rajasekaran et al., 2005; Sathish Sekar et al., 2005). Moreover, administration of N. sativa oil (Al-Awadi et al., 1985; Al-Hader et al., 1993) and safflower oil (Asgary et al., 2012) had hypoglycemic effects in diabetic rats. However, the previous studies exhibited that the essential oils of safflower and $N$. sativa and their active constituents have demonstrated free radical scavenging and antioxidant effects (Burits and Bucar, 2000; Tomaino et al., 2005; Asgary et al., 2012).

Table 1. Effect of $N$. sativa and safflower oil supplementation on body weight (g)

\begin{tabular}{|c|c|c|c|c|c|}
\hline Time & Normal & Diabetic rat & N. sativa & Safflower & $\begin{array}{c}\text { N. sativa+ } \\
\text { Safflower }\end{array}$ \\
\hline 0 day & 216.7 & 217.7 & 217.7 & 217.9 & 217.3 \\
\hline $7^{\text {th }}$ day & 236.7 & 203.7 & 207.6 & 203.6 & 206.9 \\
\hline $\mathbf{1 5}^{\text {th }}$ day & 246.0 & 198.6 & 198.3 & 196.0 & 198.7 \\
\hline $\mathbf{2 1}^{\text {th }}$ day & 258.6 & 195.4 & 210.4 & 205.6 & 207.6 \\
\hline
\end{tabular}




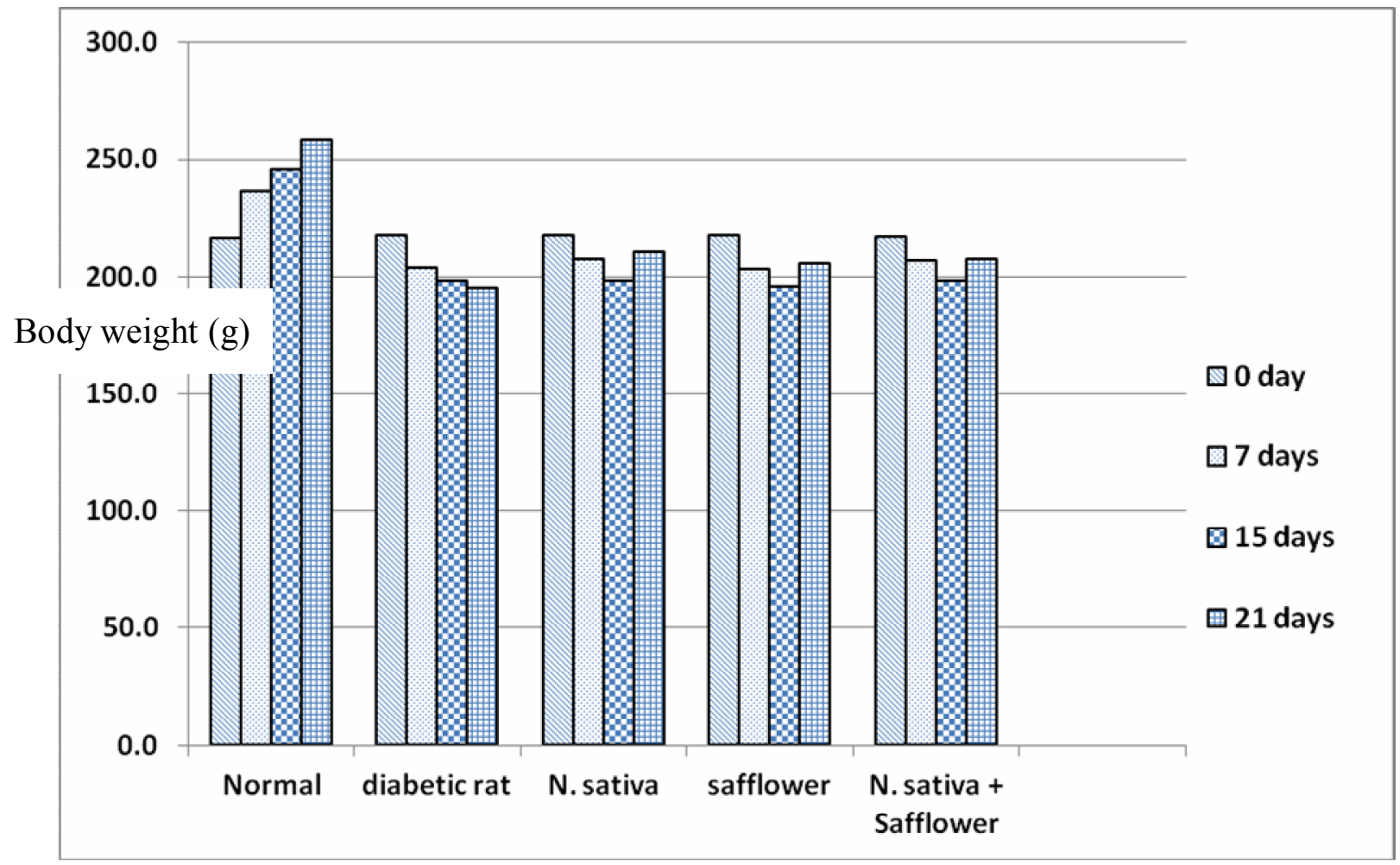

In view of previously mentioned reports, we propose that the conceivable mechanism of the studying oils action could be related to antioxidants help to recover from weak of glucose metabolism. As well as, The improvement of antioxidants in diabetics may prompt to protection of $\beta$ cells of islet cells (Fararh et al., 2002; Kanter et al., 2003; Altan et al., 2007; Abdelmeguid et al., 2010; Alimohammadi et al., 2013). This protection was associated with a significant increase in insulin production and decrease in hepatic glucose production (Fararh et al., 2004). Moreover, safflower oil is rich in a polyunsaturated essential fatty acid (80\% Linoleic acid), there is evidence that free unsaturated fats assume an essential part in insulin production and glucose homeostasis (Rahimi et al., 2014).

Table 2. Effect of $N$. sativa and safflower oil supplementation on blood glucose level $(\mathrm{mg} / \mathrm{dl})$

\begin{tabular}{|l|c|c|c|c|c|}
\hline \multicolumn{1}{|c|}{ Time } & Normal & Diabetic rat & N. sativa & Safflower & $\begin{array}{c}\text { N. sativa+ } \\
\text { Safflower }\end{array}$ \\
\hline $\mathbf{0 ~ d a y ~}$ & 93.7 & 368.4 & 371.7 & 369.1 & 370.3 \\
\hline $\mathbf{7}^{\text {th }}$ day & 94.0 & 484.3 & 309.0 & 315.0 & 316.1 \\
\hline $\mathbf{1 5}^{\text {th }}$ day & 98.4 & 484.9 & 194.1 & 285.5 & 231.3 \\
\hline $\mathbf{2 1}^{\text {th }}$ day & 96.6 & 497.3 & 133.9 & 153.7 & 142.4 \\
\hline
\end{tabular}




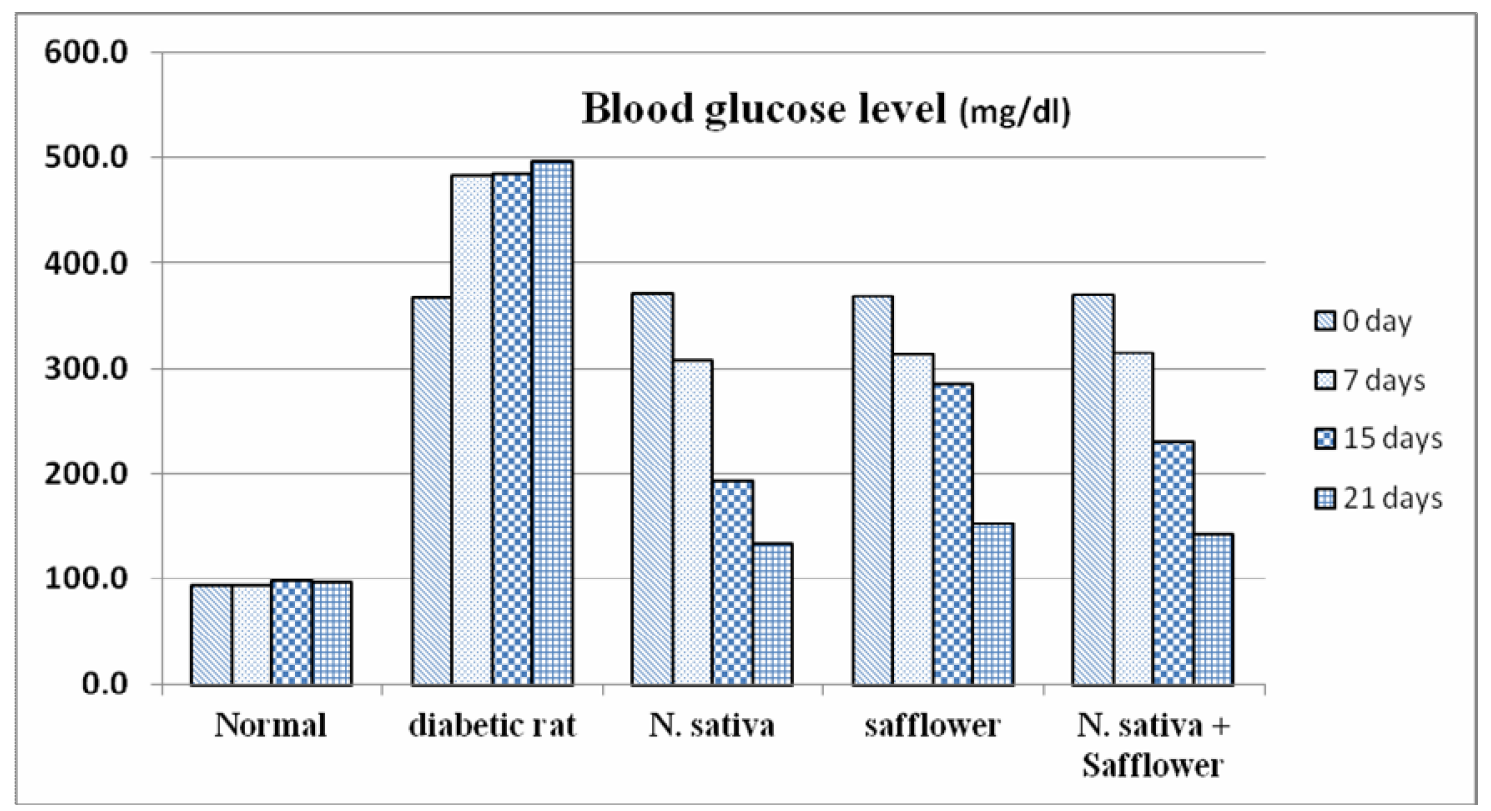

Effect of $N$. sativa and safflower oil on lipid profile:

The changes in the lipid profile in control and experimental groups are illustrated in Table 3. There was a highly significant $(p<0.001)$ increase in the level of serum cholesterol, triglyceride and LDL in STZ-induced diabetic rats compared to the controls. In contrast, there was a highly significant $(p<0.001)$ decrease in the levels of serum HDL in STZ-induced diabetic rats. These results are similar to those obtained by Bolkent et al. (2004), Ravi et al. (2005), Singh et al. (2005) and Rajasekaran et al. (2006). Abnormal high concentration of serum lipids in diabetic rats are expected fundamentally to enhance in formation of free fatty acids from peripheral fat storage, since insulin blocks the hormone-sensitive lipase
(Pushparaj et al., 2000). However, treatment of STZ-induced diabetic rats with $N$. sativa oil, safflower oil and $N$. sativa plus safflower oils resulted in a highly significant $(p<0.001)$ decrease in serum cholesterol, triglyceride and LDL levels, while a highly significant $(\mathrm{p}<0.001)$ increased in serum HDL. These finding as forementioned by Zaoui et al. (2002) and Asgary et al. (2012). Accurate mechanism of $N$. sativa action is unknown, however, it has been demonstrated that volatile oil of $N$. sativa which has role in heart disease prevention (Abdel-Aal and Attia, 1993). Furthermore, it has strong antioxidant activity by removal of different free radicals (Badary et al., 2003).

Table 3. Effect of $N$. sativa and safflower oil supplementation on lipid profile

\begin{tabular}{|l|c|c|c|c|c|}
\hline \multicolumn{1}{|c|}{ Lipid profile } & Normal & Diabetic rat & N. sativa & Safflower & $\begin{array}{c}\text { N. sativa+ } \\
\text { Safflower }\end{array}$ \\
\hline Cholesterol (mg/dl) & 74.14 & 133.71 & 85.29 & 92.57 & 88.29 \\
\hline Triglyceride (mg/dl) & 86.14 & 160.14 & 97.43 & 101.14 & 105.29 \\
\hline LDL (mg/dl) & 33.34 & 85.11 & 43.94 & 53.06 & 47.37 \\
\hline HDL (mg/dl) & 23.57 & 16.57 & 21.86 & 19.29 & 19.86 \\
\hline
\end{tabular}




\section{Effect of $N$. sativa and safflower oil on liver function tests}

Serum AST and ALT activities, as markers of liver function were highly significant increased $(\mathrm{p}<0.001)$ in the untreated diabetic animals in comparison with the control group. On the other hand, treatment of diabetic rats with $N$. sativa oil, safflower oil or $N$. sativa plus safflower oils leads to reduction of AST and ALT activities (Table 4). In- crease the activities of AST and ALT may be induced due to liver dysfunction (Navarro et al., 1993; Ohaeri, 2001), which gives an indication on the hepatotoxic effect of STZ. Moreover, administration of $N$. sativa oil, safflower oil or $N$. sativa plus safflower oils may inhibit the liver damage induced by streptozotocin (AlLogmani and Zari, 2009). Consequently, decrease the activities of AST and ALT.

Table 4. Effect of $N$. sativa and safflower oil supplementation on serum AST and $\operatorname{ALT}(\mathbf{U} / \mathbf{L})$

\begin{tabular}{|c|c|c|c|c|c|}
\hline Liver function tests & Normal & $\begin{array}{c}\text { Diabetic } \\
\text { rat }\end{array}$ & N. sativa & Safflower & $\begin{array}{c}\text { N. sativa+ } \\
\text { Safflower }\end{array}$ \\
\hline AST (U/L) & 75.9 & 141.1 & 83.1 & 89.1 & 94.6 \\
\hline ALT (U/L) & 48.1 & 76.3 & 54.1 & 59.7 & 56.9 \\
\hline
\end{tabular}

Effect of $N$. sativa and safflower oil on kidney function tests

As cleared in Table 5, the diabetic rat showed significant increase in creatinine and urea compared to the control one. Intraoral treatment with $N$. sativa, safflower or $N$. sativa plus safflower oils to diabetic rats resulted in a significant $(\mathrm{p}<0.01)$ decreased in blood urea level, in contrast there were no significant differences in creatinine level. Elevations of blood urea and creatinine concentrations in diabetic rats may be due to reduction of serum protein and increase in circulating amino leads to the formation of large amount of ammonia which is inevitably changed to urea (Gawroñska-Szklarz et al., 2003). Furthermore, the breakdown of amino acids during gluconeogenesis in the liver leads to increased urea production (Ganong, 2003).

Table 5. Effect of $N$. sativa and safflower oil supplementation on serum urea $(\mathrm{mg} / \mathrm{dl})$

\begin{tabular}{|c|c|c|c|c|c|}
\hline Kidney function tests & Normal & $\begin{array}{c}\text { Diabetic } \\
\text { rat }\end{array}$ & N. sativa & Safflower & $\begin{array}{c}\text { N. sativa+ } \\
\text { Safflower }\end{array}$ \\
\hline Creatinine (mg/dl) & 0.47 & 0.56 & 0.51 & 0.54 & 0.53 \\
\hline Urea (mg/dl) & 23.14 & 50.86 & 43.86 & 46.57 & 45.86 \\
\hline
\end{tabular}

\section{Effect of $N$. sativa and safflower oil on total protein}

A highly significant $(\mathrm{p}<0.001)$ decrease in blood total protein compared to the control. There were no significant differences in the levels of protein after treatment of the diabetic rats by $N$. sativa, safflower or $N$. sativa plus safflower oils (Table 6). The pervious result is consistent with the 
finding of (Peavy et al., 1985; Wanke and Wong, 1991). This decrease might be because of suppression of oxidative phosphorylation which, result in decline of protein synthesis, increase in the catabolic processes and reduction of protein absorption (Tragl and Reaven, 1972; Jefferson et al., 1983).

Table 6. Effect of $N$. sativa and safflower oil supplementation on total protein $(\mathrm{g} / \mathrm{L})$

\begin{tabular}{|l|c|c|c|c|c|}
\hline & Normal & Diabetic rat & N. sativa & Safflower & $\begin{array}{c}\text { N. sativa+ } \\
\text { Safflower }\end{array}$ \\
\hline Total protein (g/L) & 6.31 & 5.96 & 6.01 & 5.96 & 6.03 \\
\hline
\end{tabular}

\section{Conclusion}

The results of this research appear that $N$. sativa, safflower or $N$. sativa plus safflower oils have antidiabetic and antilipidemic effects in diabetic rats so, recommend that these oils might be a valuable cure for diabetes.

\section{References:}

Abdel-Aal, E.-S. and Attia, R., (1993). Characterization of Black cumin (Nigella sativa) seeds 1-Chemical composition and lipids. Alexandria Science Exchange 14, 467-467.

Abdel-Sater, K. A., (2009). Short Communication Gastroprotective effects of Nigella Sativa oil on the formation of stress gastritis in hypothyroidal rats. Int J Physiol Pathophysiol Pharmacol 1, 143149.

Abdelmeguid, N. E.; Fakhoury, R.; Kamal, S. M. and Al Wafai, R. J., (2010). Effects of Nigella sativa and thymoquinone on biochemical and subcellular changes in pancreatic $\quad \beta$-cells of streptozotocin-induced diabetic rats. Journal of Diabetes 2, 256266.

Abel-Salam, B. K., (2012). Immunomodulatory effects of black seeds and garlic on alloxaninduced Diabetes in albino rat. Allergologia et immunopathologia 40, 336-340.
Al-Awadi, F.; Khattar, M. and Gumaa, K., (1985). On the mechanism of the hypoglycaemic effect of a plant extract. Diabetologia 28, 432-434.

Al-Hader, A.; Aqel, M. and Hasan, Z., (1993). Hypoglycemic effects of the volatile oil of Nigella sativa seeds. International journal of pharmacognosy 31, 96-100.

Al-Logmani, A. S. and Zari, T. A., (2009). Effects of Nigella sativa L. and Cinnamomum zeylanicum Blume oils on some physiological parameters in streptozotocininduced diabetic rats. Bol Latinoam Caribe Plant Med Aromat 8, 86-96.

Ali, B. and Blunden, G., (2003). Pharmacological and toxicological properties of Nigella sativa. Phytotherapy Research 17, 299305.

Alimohammadi, S.; Hobbenaghi, R.; Javanbakht, J.; Kheradmand, D.; Mortezaee, R.; Tavakoli, M.; Khadivar, F. and Akbari, H., (2013). Protective and antidiabetic effects of extract from Nigella sativa on blood glucose concentrations against streptozotocin (STZ)-induced diabetic in rats: an experimental study with histopathological evaluation. Diagn Pathol 8, 137.

AlRawi, M. M., (2007). Effect of Trifolium sp. flowers extracts on the status of liver histology of 
streptozotocin-induced diabetic rats.

Altan, M. F.; Kanter, M.; Donmez, S.; Kartal, M. E. and Buyukbas, S., (2007). Combination therapy of Nigella sativa and human parathyroid hormone on bone mass, biomechanical behavior and structure in streptozotocin-induced diabetic rats. Acta histochemica 109, 304-314.

Ananthi, J.; Prakasam, A. and Pugalendi, K., (2003). Antihyperglycemic activity of Eclipta alba leaf on alloxan-induced diabetic rats. The Yale journal of biology and medicine 76, 97.

Arici, M.; Sagdic, O. and Gecgel, U., (2005). Antibacterial effect of Turkish black cumin (Nigella sativa L.) oils. Grasas y Aceites 56, 259-262.

Asgary, S.; Rahimi, P.; Mahzouni, P. and Madani, H., (2012). Antidiabetic effect of hydroalcoholic extract of Carthamus tinctorius L. in alloxaninduced diabetic rats. Journal of Research in Medical Sciences 17.

Augusti, K. and Sheela, C., (1996). Antiperoxide effect of S-allyl cysteine sulfoxide, an insulin secretagogue, in diabetic rats. Experientia 52, 115-119.

Badary, O. A.; Taha, R. A.; Gamal ElDin, A. M. and Abdel-Wahab, M. H., (2003). Thymoquinone is a potent superoxide anion scavenger. Drug and chemical toxicology 26, 87-98.

Bolkent, Ş.; Yanardağ, R.; KarabulutBulan, Ö. and Özsoy-Saçan, Ö., (2004). The morphological and biochemical effects of glibornuride on rat liver in experimental diabetes. Human \& experimental toxicology 23, 257-264.

Bonnefont-Rousselot, D.; Bastard, J.; Jaudon, M. and Delattre, J.,
(2000). Consequences of the diabetic status on the oxidant/antioxidant balance. Diabetes and Metabolism 26, 163177.

Bourgou, S.; Pichette, A.; Marzouk, B. and Legault, J., (2012). Antioxidant, anti-inflammatory, anticancer and antibacterial activities of extracts from Nigella sativa (black cumin) plant parts. Journal of Food Biochemistry 36, 539-546.

Burits, M. and Bucar, F., (2000). Antioxidant activity of Nigella sativa essential oil. Phytotherapy Research 14, 323-328.

Campos, K.; Diniz, Y.; Cataneo, A.; Faine, L.; Alves, M. and Novelli, E., (2003). Hypoglycaemic and antioxidant effects of onion, Allium cepa: dietary onion addition, antioxidant activity and hypoglycaemic effects on diabetic rats. International journal of food sciences and nutrition 54, 241-246.

Choi, E. M.; Kim, G. H. and Lee, Y. S., (2010). Carthamus tinctorius flower extract prevents $\mathrm{H} 2 \mathrm{O} 2-$ induced dysfunction and oxidative damage in osteoblastic MC3T3-E1 cells. Phytotherapy Research 24, 1037-1041.

El Mezayen, R.; El Gazzar, M.; Nicolls, M. R.; Marecki, J. C.; Dreskin, S. C. and Nomiyama, H., (2006). Effect of thymoquinone on cyclooxygenase expression and prostaglandin production in a mouse model of allergic airway inflammation. Immunology letters $106,72-81$.

Fararh, K.; Atoji, Y.; Shimizu, Y. and Takewaki, T., (2002). Isulinotropic properties of Nigella sativa oil in Streptozotocin plus Nicotinamide diabetic hamster. Research in Veterinary Science 73, 279-282. 
Fararh, K.; Atoji, Y.; Shimizu, Y.; Shiina, T.; Nikami, H. and Takewaki, T., (2004). Mechanisms of the hypoglycaemic and immunopotentiating effects of Nigella sativa L. oil in streptozotocin-induced diabetic hamsters. Research in veterinary science 77, 123-129.

Farouque, H. O. and Meredith, I. T., (2003). Effects of inhibition of ATP-sensitive potassium channels on metabolic vasodilation in the human forearm. Clinical Science 104, 39-46.

Fernstrom, M. H. and Fernstrom, J. D., (1993). Large changes in serum free tryptophan levels do not alter brain tryptophan levels: studies in streptozotocin-diabetic rats. Life sciences 52, 907-916.

Ganong, W. F., (2003). Review of medical physiology,. 2 Ed., Lange Medical Books, McGraw-Hill, New York.

Gawroñska-Szklarz, B.; Musial, D.; Pawlik, A. and Paprota, B., (2003). Effect of experimental diabetes on pharmacokinetic parameters of lidocaine and MEGX in rats. Pol J Pharmacol 55, 619-624.

Goreja, W., (2003). Black seed: nature's miracle remedy. Karger Publishers.

Halawani, E., (2009). Antibacterial activity of thymoquinone and thymohydroquinone of Nigella sativa $L$. and their interaction with some antibiotics. Advances in Biological Research 3, 148-152.

Hayoz, D.; Ziegler, T.; Brunner, H. R. and Ruiz, J., (1998). Diabetes mellitus and vascular lesions. Metabolism 47, 16-19.

Hiramatsu, M.; Takahashi, T.; Komatsu, M.; Kido, T. and Kasahara, Y., (2009). Antioxidant and neuroprotective activities of Mogami-benibana (safflower,
Carthamus tinctorius Linne). Neurochemical research 34, 795805.

Howarth, F.; Jacobson, M.; Naseer, O. and Adeghate, E., (2005). Shortterm effects of streptozotocininduced diabetes on the electrocardiogram, physical activity and body temperature in rats. Experimental physiology 90, 237-245.

Jefferson, L. S.; Liao, W.; Peavy, D.; Miller, T.; Appel, M. and Taylor, J., (1983). Diabetes-induced alterations in liver protein synthesis. Changes in the relative abundance of mRNAs for albumin and other plasma proteins. Journal of Biological Chemistry 258, 1369-1375.

Kanter, M.; Meral, I.; Yener, Z.; Ozbek, H. and Demir, H., (2003). Partial Regeneration/Proliferation of the. BETA.-Cells in the Islets of Langerhans by Nigella sativa L. in Streptozotocin-Induced Diabetic Rats. The Tohoku journal of experimental medicine 201, 213219.

Kumar, G. R. and Reddy, K. P., (1999). Reduced nociceptive responses in mice with alloxan induced hyperglycemia after garlic (Allium sativum Linn.) treatment. Indian J Exp Biol 37, 662-666.

Liu, Y.; Yang, J. and Liu, Q., (2005). [Studies on chemical constituents from the flowers of Carthamus tinctorius L]. Zhong yao cai= Zhongyaocai $=$ Journal of Chinese medicinal materials 28, 288-289.

Mahmoud, S. S. and Torchilin, V. P., (2013). Hormetic/cytotoxic effects of Nigella sativa seed alcoholic and aqueous extracts on MCF-7 breast cancer cells alone or in combination with doxorubicin. Cell biochemistry and biophysics 66, 451-460. 
Navarro, M. C.; MONTIALLA, M.; Martín, A.; Jiménez, J. and Utrilla, M. P., (1993). Free radical scavenger and antihepatotoxic activity of Rosmarinus tomentosus. Planta Medica 59, 312-314.

Ohaeri, O., (2001). Effect of garlic oil on the levels of various enzymes in the serum and tissue of streptozotocin diabetic rats. Bioscience reports 21, 19-24.

Padhye, S.; Banerjee, S.; Ahmad, A.; Mohammad, R. and Sarkar, F. H., (2008). From here to eternity-the secret of Pharaohs: Therapeutic potential of black cumin seeds and beyond. Cancer therapy 6, 495.

Peavy, D. E.; Taylor, J. M. and Jefferson, L. S., (1985). Time course of changes in albumin synthesis and mRNA in diabetic and insulin-treated diabetic rats. American Journal of PhysiologyEndocrinology and Metabolism 248, E656-E663.

Pushparaj, P.; Tan, C. and Tan, B., (2000). Effects of Averrhoa bilimbi leaf extract on blood glucose and lipids in streptozotocin-diabetic rats. Journal of Ethnopharmacology 72, 69-76.

Rahimi, P.; Asgary, S. and Kabiri, N., (2014). Hepatoprotective and Hypolipidemic Effects of Carthamus tinctorius oil in Alloxan-induced Type 1 Diabetic Rats. Journal of HerbMed Pharmacology 3, 107-111.

Rajasekaran, S.; Ravi, K.; Sivagnanam, K. and Subramanian, S., (2006). Beneficial effects of Aloe vera leaf gel extract on lipid profile status in rats with streptozotocin diabetes. Clinical and Experimental Pharmacology and Physiology 33, 232-237.

Rajasekaran, S.; Sivagnanam, K. and Subramanian, S., (2005).
Antioxidant effect of Aloe vera gel extract in streptozotocin-induced diabetes in rats. Pharmacol Rep 57, 90-96.

Ravi, K.; Ramachandran, B. and Subramanian, S., (2004). Protective effect of Eugenia jambolana seed kernel on tissue antioxidants in streptozotocininduced diabetic rats. Biological and Pharmaceutical Bulletin 27, 1212-1217.

Ravi, K.; Rajasekaran, S. and Subramanian, S., (2005). Antihyperlipidemic effect of Eugenia jambolana seed kernel on streptozotocin-induced diabetes in rats. Food and Chemical Toxicology 43, 1433-1439.

Rchid, H.; Chevassus, H.; Nmila, R.; Guiral, C.; Petit, P.; Chokaïri, M. and Sauvaire, Y., (2004). Nigella sativa seed extracts enhance glucose-induced insulin release from rat-isolated Langerhans islets. Fundamental \& clinical pharmacology 18, 525-529.

Salama, R. H. M., (2012). Effect of lipoic acid, carnitine and nigella sativa on diabetic rat model. International journal of health sciences 5.

Sathish Sekar, D.; Sivagnanam, K. and Subramanian, S., (2005). Antidiabetic activity of Momordica charantia seeds on streptozotocin induced diabetic rats. Die Pharmazie-An International Journal of Pharmaceutical Sciences 60, 383387.

Shuid, A. N.; Mohamed, N.; Mohamed, I. N.; Othman, F.; Suhaimi, F.; Mohd Ramli, E. S.; Muhammad, N. and Soelaiman, I. N., (2012). Nigella sativa: A potential antiosteoporotic agent. EvidenceBased Complementary and Alternative Medicine 2012. 
Singh, N.; Kamath, V. and Rajini, P., (2005). Protective effect of potato peel powder in ameliorating oxidative stress in streptozotocin diabetic rats. Plant foods for human nutrition 60, 49-54.

Tomaino, A.; Cimino, F.; Zimbalatti, V.; Venuti, V.; Sulfaro, V.; De Pasquale, A. and Saija, A., (2005). Influence of heating on antioxidant activity and the chemical composition of some spice essential oils. Food Chemistry 89, 549-554.

Tragl, K. H. and Reaven, G. M., (1972). Effect of insulin deficiency on hepatic ribosomal aggregation. Diabetes 21, 84-88.

Umar, S.; Zargan, J.; Umar, K.; Ahmad, S.; Katiyar, C. K. and Khan, H. A., (2012). Modulation of the oxidative stress and inflammatory cytokine response by thymoquinone in the collagen induced arthritis in Wistar rats. Chemico-biological interactions 197, 40-46.
Vats, V.; Yadav, S. and Grover, J., (2004). Ethanolic extract of Ocimum sanctum leaves partially attenuates streptozotocin-induced alterations in glycogen content and carbohydrate metabolism in rats. Journal of ethnopharmacology 90 , 155-160.

Wanke, I. and Wong, N., (1991). Diabetes mellitus decreases the activity of the albumin promoter in vitro. Journal of Biological Chemistry 266, 6068-6072.

Yoon, K.-H.; Lee, J.-H.; Kim, J.-W.; Cho, J. H.; Choi, Y.-H.; Ko, S.-H.; Zimmet, P. and Son, H.-Y., (2006). Epidemic obesity and type 2 diabetes in Asia. The Lancet 368, 1681-1688.

Zaoui, A.; Cherrah, Y.; Alaoui, K.; Mahassine, N.; Amarouch, H. and Hassar, M., (2002). Effects of Nigella sativa fixed oil on blood homeostasis in rat. Journal of Ethnopharmacology 79, 23-26. 
تأثير زيت حبة البركة وزيت القرطم علي بعض المعايير البيوكيميائية في الفئران المصابة

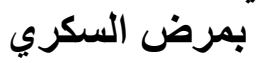

روفيدة فرج محمد مفتاح، محمد رشوان عبد العال رشوان، عبدالله صالح عبد الجواد، ماجدة عبد الحميد احمد سليم

قسم علوم وتكنولوجيا الأغذية ـ كلية الزراعة ـ جامعة أسيوط

تم در اسابة تأثير زيت حبة البركة وزيت القرطم على بعض المعايير البيو كيميائية في ذكور

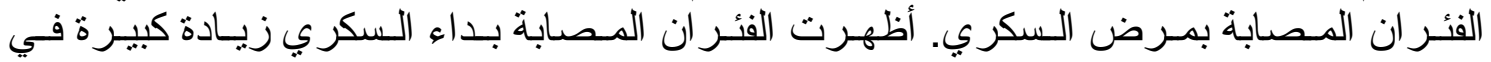

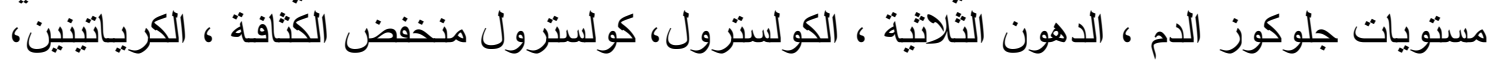

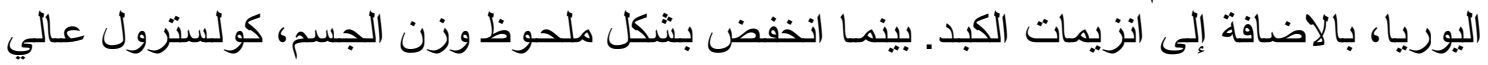

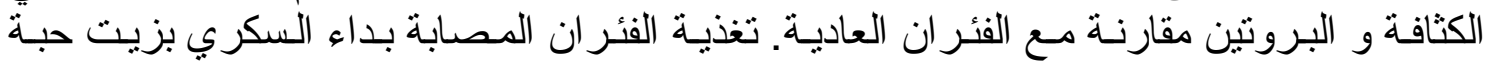

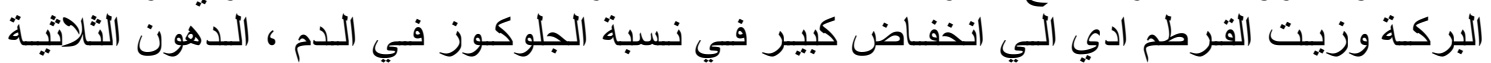

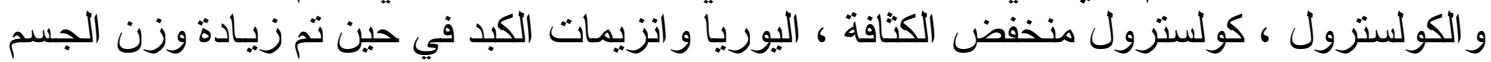

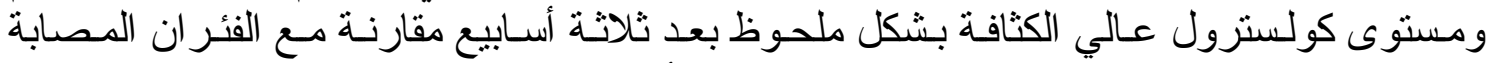

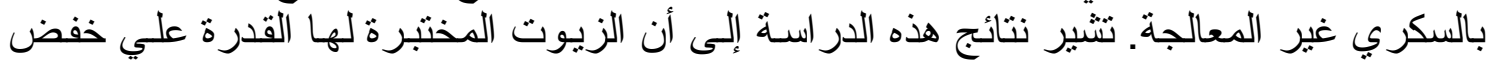
مستوي ألسكر و الدهون في الدم في الفئران المصابة بداء النئ السكري. 